\section{The Action of Acid Proteinase from Aspergillus oryzae on Soybean Proteins ${ }^{\dagger}$}

\author{
Tadanobu Nakadar and Seiichi Nasuno

\begin{abstract}
Noda Institute for Scientific Research,
\end{abstract} \\ Noda, Chiba
}

Received September 24, 1976

Until recently it has long been considered that large amounts of free amino acids are liberated from proteins by the hydrolytic action of acid protease of Aspergillus oryzae. ${ }^{1 \sim 5)}$ Yoshii has reported that free amino acids are liberated from soybean proteins by acid protease in miso (soybean paste) brewing. ${ }^{8}$ ) Recently however, crude acid proteinases are reported to be contaminated with acid carboxypeptidase in cases of $A$. oryzae, $^{7)} \dot{A}$. saito $^{82}$ and $A$. niger ${ }^{0,10)}$ This suggests that liberation of free amino acid in miso brewing is due to the action of carboxypeptidase of the mold.

In this connection, the present paper deals with separation of acid proteinase from acid carboxypeptidase and hydrolytic action of each enzyme on ALPHAprotein.

Acid proteinase from $A$. oryzae 460 was not separated from acid carboxypeptidase IV by column chromatography on DEAE-cellulose, DEAE-Sephadex A-50, hydroxylapatite, P-cellulose and gel filtration through Sephadex G-100. The partially purified enzyme preparation separated by the above-mentioned methods was dissolved in $150 \mu \mathrm{l}$ of $20 \%$ sucrose and spacer gels were omitted. Each of $10 \mu \mathrm{l}$ of enzyme solution was applied to polyacrylamide gel disc electrophoresis at pH 4.0 (12 columns). ${ }^{113} \quad$ Electrophoresis was run in a cold room $\left(4^{\circ} \mathrm{C}\right)$ for $7 \mathrm{hr}$ at $4 \mathrm{~mA}$ per gel column. Frozen gels were sliced laterally into discs $2 \mathrm{~mm}$ thick, extracted overnight at $4^{\circ} \mathrm{C}$ with $1 \mathrm{ml}$ of $0.05 \mathrm{M}$ acetate buffer at $\mathrm{pH} 4.5$ and enzyme activity was assayed with an aliquot of each extract. Figure 1 shows typical electrophoretic patterns of acid proteinase and acid carboxypeptidase IV $^{12)}$ from $A$. oryzae. Fractions 7 to 9 were collected, desalted by dialysis and used as acid proteinase.

Acid proteinase has an optimun $\mathrm{pH}$ of 3.7 for milk casein. The molecular weight of the enzyme was estimated to be about 39,000 by the gel filtration method. ${ }^{13)}$

Table I shows some results on hydrolysis of soybean ALPHA-protein by 18.1 PU of purified acid proteinase $(254 \mu \mathrm{g})$ containing trace $\left(526 \times 10^{-5}\right.$ unit, protein;

$\uparrow$ The work of this paper was presented at the Annual Meeting of Japan Soy Sauce Research Institute, held on April 2, 1975.

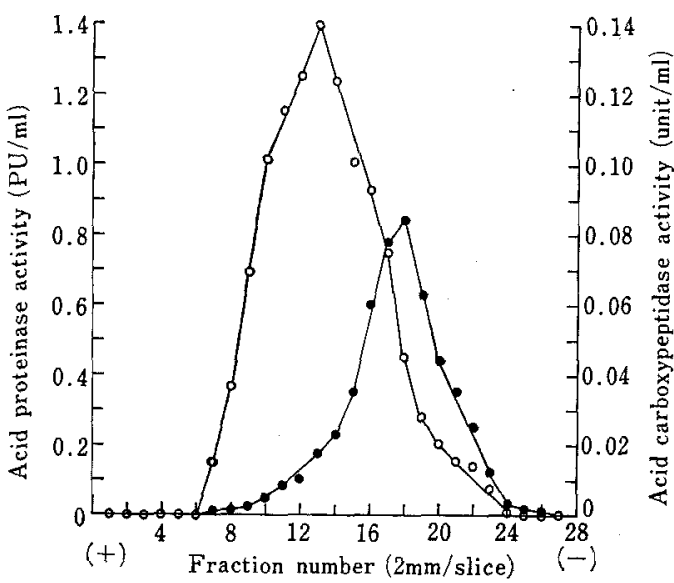

FIG. 1. Polyacrylamide Gel Electrophoresis of Acid Proteinase.

Electrophoresis was run in a cold room $\left(4^{\circ} \mathrm{C}\right)$ for $7 \mathrm{hr}$ at $4 \mathrm{~mA}$ per gel column at $\mathrm{pH} 4.0$.

$\mathrm{O}-\mathrm{O}$, proteinase activity on casein $(\mathrm{pH} 3.0)$; -carboxypeptidase activity on Cbz-Glu-Tyr (pH 3.0).

TABle I. Hydrolysis of $\alpha$-Protein BY Acid Proteinase from $A$. oryzae

\begin{tabular}{lc}
\hline T. N. & $0.0252 \%$ \\
F. N. & $0.0028 \%$ \\
Glu. & $0 \mathrm{mg} / \mathrm{ml}$ \\
N. P. ${ }^{a}$ ) & $0.227 \mathrm{mg} / \mathrm{ml}$ \\
HCl-N. P. $\left.{ }^{b}\right)$ & $1.525 \mathrm{mg} / \mathrm{ml}$ \\
F. N./T. N. & $11.0 \%$ \\
T. N./F. N. ${ }^{c}$ ) & 9.00 \\
HCl-N. P.N. P. & 6.71
\end{tabular}

a) Ninhydrin positive substances determined as glutamic acid.

b) Ninhydrin positive substances determined as glutamic acid after re-hydrolysis with $\mathrm{HCl}$ of enzyme digested products.

c) Indicates an average number of amino acids in peptides molecules.

$0.39 \mu \mathrm{g}$ ) of acid carboxypeptidase $\mathrm{IV}^{12)}$ at $\mathrm{pH} 5.0$ for 12 days at $30^{\circ} \mathrm{C}^{14}$ ) Commercially available ALPHAprotein (trade-mark) derived from soybeans was obtained from Nutritional Biochemicals Corporation (T. N.; 14.24\%). No glutamic acid (Glu.) was found in the hydrolyzate by acid proteinase and only very low value of formol nitrogen (F. N.) was obtained. The hydrolyzed products seemed to be peptides consisted of 7 to 9 amino acids, but not to be free amino acids based on the ratio of T.N.F.N. and on the increase of ninhydrin positive substances after rehydrolysis with $\mathrm{HCl}$.

Next, ALPHA-protein was hydrolyzed by a mixture of $157 \mathrm{PU}$ of acid proteinase and 5.38 units of acid 
TABLE II. HydRolysis OF $\alpha$-PROTEIN BY THE Mixture of Acm Proteinase and Acid CarboXypeptidase IV from $A$, oryzae

\begin{tabular}{lc}
\hline T.N. & $0.0642 \%$ \\
F.N. & $0.0175 \%$ \\
Glu. & $0.233 \mathrm{mg} / \mathrm{ml}$ \\
F.N./T. N. & $27.2 \%$ \\
T. N./F. N. ${ }^{\alpha)}$ & 3.67 \\
\hline
\end{tabular}

a) Indicates an average number of amino acids in peptide molecules.

carboxypeptidase IV partially purified without disc electrophoresis at $\mathrm{pH} 5.0$ and $30^{\circ} \mathrm{C}$ for 3 days. As shown in Table II, some glutamic acid was detected in the hydrolyzate and a comparable value of formol nitrogen to total nitrogen was found in this case.

Acid proteinase showed neither carboxypeptidase nor aminopeptidase activity. Acid proteinase was found to be a typical endopeptidase liberating only little free amino acids from protein. The mixed preparation of acid proteinase and acid carboxypeptidase IV formed large amounts of free amino acids.

These results clealy indicate that free amino acids are liberated from soybean protein by the hydrolytic action of both acid proteinase and acid carboxypeptidase of $A$. oryzae in the miso brewing, but not liberated by the hydrolytic action of only acid proteinase.

Acknowledgement. The authors wish to thank late Dr. T. Asai, Dr. K. Sakaguchi, Profs. H. Takahashi,
K. Shimura, K. Matsuda, K. Arima and Y. Ikeda for their kind guidance and Dr. K. Hayashi for his useful suggestion. The authors acknowledge Mrs. M. Moromachi, Miss T. Masuda and Mrs. Y. Otsuka for their technical assistance.

\section{REFERENCES}

1) Y. Nunokawa, Y. Namba and Y. Kinuyama, Nippon Nôgeikagaku Kaishi, 36, 879 (1962).

2) Y. Nunokawa, ibid., 36, 884 (1962).

3) K. Kuruma and Y. Nunokawa, ibid., 42, 319 (1968).

4) T. Ishikawa and Y. Nunokawa, ibid., 44, 21 (1970).

5) Y. Nunokawa, J. Soc. Brew. Japan, 59, 25 (1964).

6) H. Yoshii, ibid., 68, 895 (1973).

7) T. Oka and K. Morihara, Nippon Nôgeikagaku Kaishi, 47, 367 (1973).

8) E. Ichishima, Biochim. Biophys. Acta, 258, 274 (1972).

9) T. Oka and K. Morihara, Arch. Biochem. Biophys., 156, 543 (1973).

10) K. Iio and M. Yamazaki, J. Biochem. (Japan), 46, 433 (1974).

11) R. A. Reisfeld, U. J. Lewis and D. E. Williams, Nature, 195, 281 (1962).

12) T. Nakadai, S. Nasuno and N. Iguchi, Agric. Biol. Chem., 37, 1237 (1973).

13) P. Andrews, Biochem. J., 96, 595 (1965).

14) T. Nakadai, S. Nasuno and N. Iguchi, Agric. Biol. Chem., 36, 261 (1972). 